\title{
PENGARUH ZPT HORMONIK TERHADAP PRODUKSI TIGA VARIETAS CABAI BESAR (Capsicum annum L.)
}

\author{
Tati Hariyati dan Fajwati \\ Fakultas Pertanian Universitas Kaltara \\ Email : tati_hariyati79@yahoo.co.id / fajwatianakunikal@gmai.com
}

\begin{abstract}
ABSTRAK
Penelitian ini bertujuan untuk mengetahui pengaruh zat pengatur tumbuh hormonik terhadap proses partenokarpi pada tiga varietas tanaman cabai besar dan untuk mengetahui pengaruh zat pengatur tumbuh hormonik yang optimum terhadap proses partenokarpi pada tiga varietas cabai besar. Penelitian ini dilaksanakan di Tanjung Selor, pada bulan Januari hingga Mei 2016. Rancangan yang digunakan dalam penelitian ini adalah Rancangan Acak Lengkap (RAL) dengan dua faktor dan sembilan ulangan. Faktor pertama adalah perlakuan hormonik yang terdiri dari empat taraf yaitu 0 ppm, 1 ppm, 2 ppm, 3 ppm, faktor kedua adalah varietas Arimbi, Darmais dan Pilar. Dari hasil analisis sidik ragam menunjukkan bahwa perlakuan hormonik terhadap varietas berpengaruh sangat nyata terhadap parameter berat buah pertanaman, jumlah buah pertanaman, panjang buah persampel dan jumlah biji buah persampel panen, uji lanjut BNT 5\% maka berat buah pertanaman dan jumlah buah pertanaman panen pertama tidak berbeda nyata, namun berbeda nyata terhadap panjang buah persampel dan jumlah biji buah persampel panen pertama.
\end{abstract}

Kata Kunci : Hormonik, Varietas, Partenokarpi

\begin{abstract}
This study aims to determine the effect of growth regulators Hormonik against Parthenocarpy process on three major varieties of pepper plants and to determine the effect of plant growth regulator that is optimum for the process Hormonik Parthenocarpy in three major varieties of chili. This research was conducted in Tanjung Selor, in January to May 2016. The design used in this study is completely randomized design (CRD) with two factors and nine replications. The first factor is the treatment Hormonik consisting of four levels ie 0 cc, $1 \mathrm{cc}, 2 \mathrm{cc}, 3 \mathrm{cc}$, the second factor is the variety Arielle, Darmais and Pilar. From the analysis of variance showed that the treatment Hormonik to varieties of very significant effect on the parameters of heavy fruit crop, the number of fruit crops, fruit length persampel and the number of seeds persampel first harvest, after a further test using LSD 5\%, by weight of fruit crops and the amount of fruit planting the first crop was not significantly different, but significantly different with persampel fruit length and number of seeds persampel first harvest.
\end{abstract}

Keywords: Hormonik, Variety, Parthenocarpy

\section{PENDAHULUAN}

Cabe merupakan jenis sayuran buah yang sangat dibutuhkan oleh masyarakat, cabai banyak digunakan sebagai bahan industri seperti saos, campuran bahan makanan seperti acar, dan lainnya, diibaratkan makan tanpa garam kurang nikmat rasanya. Buah Partenokarpi telah dimanfaatkan dalam meningkatkan mutu buah baik kualitas maupun produksi buah, khususnya pada jenis tanaman hortikultura yang dikomersilkan.

Buah cabai yang baik ditentukan oleh ukuran buah, bentuk buah, warna buah dan keadaan kulit buah. Untuk meningkatkan kualitas buah dapat di lakukan dengan pembentukan buah partenokarpi salah satu upaya untuk meningkatkan kualitas dan kuantitas buah salah satunya diberikan hormonik. Penelitian ini bertujuan untuk mengetahui pengaruh zpt hormonik terhadap tiga 
varietas tanaman cabai besar dan untuk mengetahui dosis hormonik yang optimum.

\section{METODOLOGI PENELITIAN}

\section{Tempat dan Waktu}

Penelitian dilaksanakan di Kota Tanjung Selor, Kalimantan Utara pada Bulan Januari-Mei 2018.

\section{Alat dan Bahan}

Alat yang digunakan meliputi cangkul, parang, meteran, talirafia, polibag pipet tetes, penggaris, timbangan digital, gembor, hand spayer, ember, dan kamera, sedangkan bahan yang digunakan 3 varietas cabai merah besar yaitu $V$. Arimbi, V. Darmais, dan V. Pilar, hormonik, pupuk bokasi dan POC Nasa.

\section{Metode Penelitian}

Penelitian ini menggunakan metode Rancangan Acak Lengkap (RAL) dengan dua faktor yaitu:

Faktor I : Perlakuan hormonik $(\mathrm{H})$ yang terdiri dari 4 taraf yaitu:

$$
\begin{aligned}
& \mathrm{H}_{0}=\text { Tanpa perlakuan } \\
& \mathrm{H}_{1}=1 \mathrm{cc} \text { pertanaman } \\
& \mathrm{H}_{2}=2 \mathrm{cc} \text { pertanaman } \\
& \mathrm{H}_{3}=3 \mathrm{cc} \text { pertanaman }
\end{aligned}
$$

Faktor II : Penggunaan 3 varietas (V) yaitu:

$$
\begin{aligned}
& \mathrm{V}_{1}=\text { Varietas Arimbi } \\
& \mathrm{V}_{2}=\text { Varietas Darmais } \\
& \mathrm{V}_{3}=\text { Varietas Pilar }
\end{aligned}
$$

Tabel 1. Kombinasi kedua perlakuan

\begin{tabular}{ccccc}
\hline \multirow{2}{*}{ Faktor II } & \multicolumn{4}{c}{ Faktor I } \\
\cline { 2 - 5 } & $\mathrm{H}_{0}$ & $\mathrm{H}_{1}$ & $\mathrm{H}_{2}$ & $\mathrm{H}_{3}$ \\
\hline $\mathrm{V}_{1}$ & $\mathrm{~V}_{1} \mathrm{H}_{0}$ & $\mathrm{~V}_{1} \mathrm{H}_{1}$ & $\mathrm{~V}_{1} \mathrm{H}_{2}$ & $\mathrm{~V}_{1} \mathrm{H}_{3}$ \\
$\mathrm{~V}_{2}$ & $\mathrm{~V}_{2} \mathrm{H}_{0}$ & $\mathrm{~V}_{2} \mathrm{H}_{1}$ & $\mathrm{~V}_{2} \mathrm{H}_{2}$ & $\mathrm{~V}_{2} \mathrm{H}_{3}$ \\
$\mathrm{~V}_{3}$ & $\mathrm{~V}_{3} \mathrm{H}_{0}$ & $\mathrm{~V}_{3} \mathrm{H}_{1}$ & $\mathrm{~V}_{3} \mathrm{H}_{2}$ & $\mathrm{~V}_{3} \mathrm{H}_{3}$ \\
\hline
\end{tabular}

Berdasarkan Tabel 1 diatas terdapat 12 perlakuan, setiap perlakuan diulang sebanyak 9 kali sehingga diperoleh 108 perlakuan, penempatan perlakuan dilakukan secara acak.

\section{HASIL DAN PEMBAHASAN}

Dari hasil analisis data sidik ragam diperoleh bahwa aplikasi zat pengatur tumbuh hormonik berpengaruh sangat nyata terhadap semua parameter hasil tanaman cabai besar yaitu berat buah per tanaman (g), jumlah buah per tanaman (buah) panjang buah pertanaman $(\mathrm{cm})$, jumlah biji buah per sampel (biji).

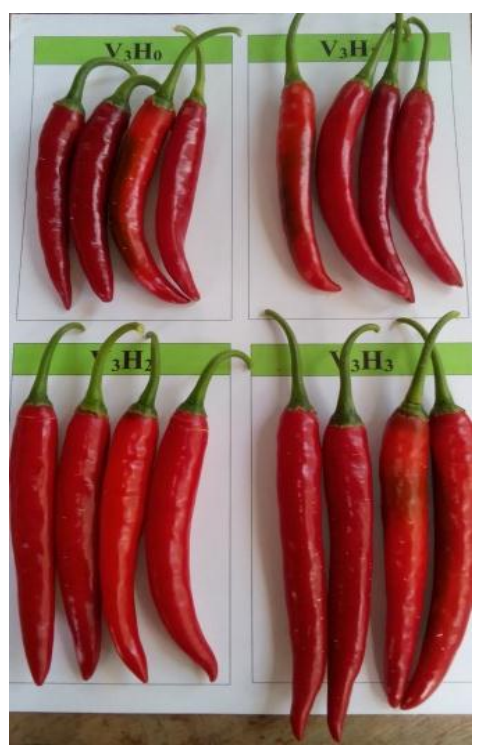

Gambar 1. Cabai Besar 
Berdasarkan data pengamatan dapat diperoleh rata-rata sebagai berikut :

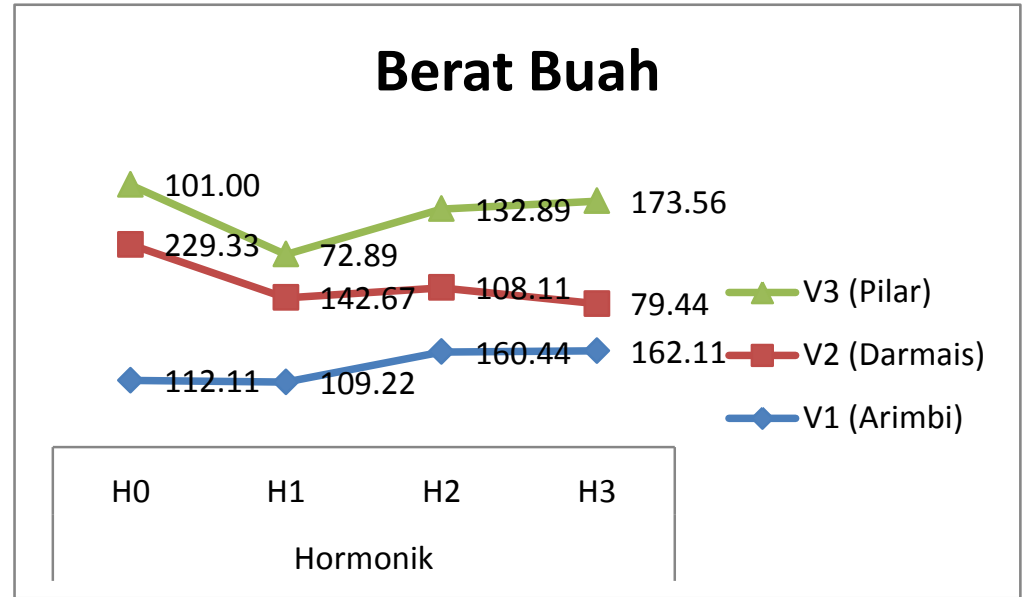

Grafik 1. Berat Buah

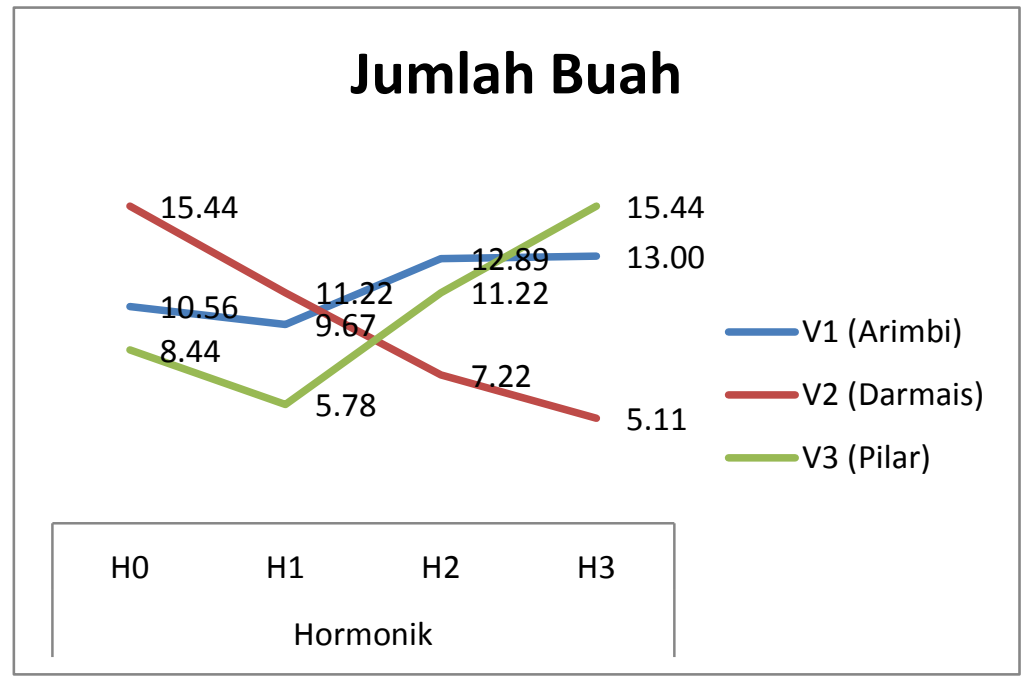

Grafik 2. Jumlah Buah pertanaman

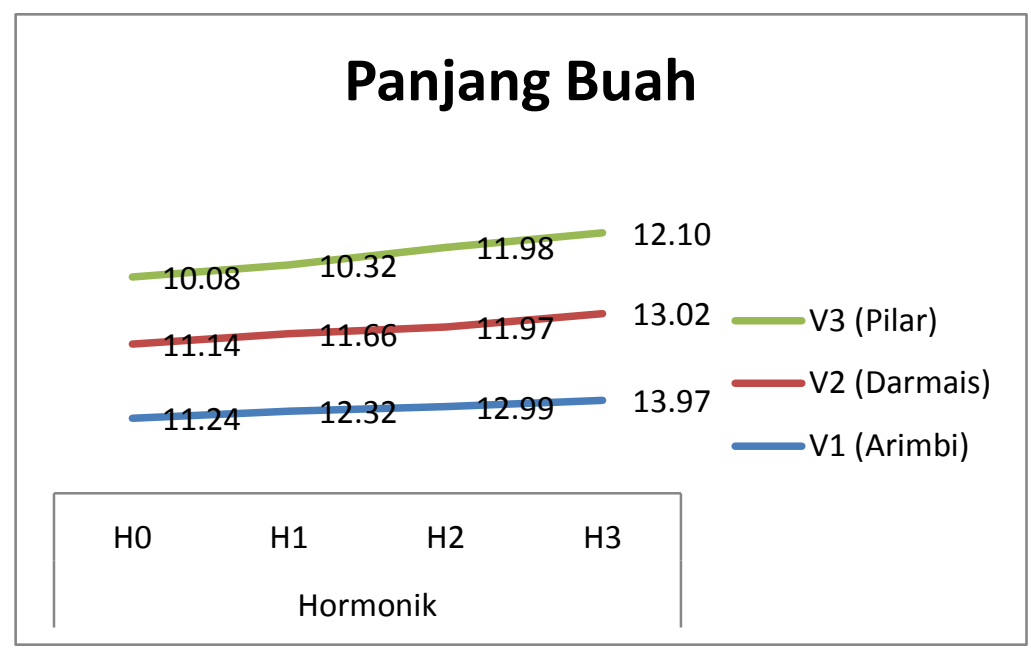

Grafik 3. Panjang Buah 


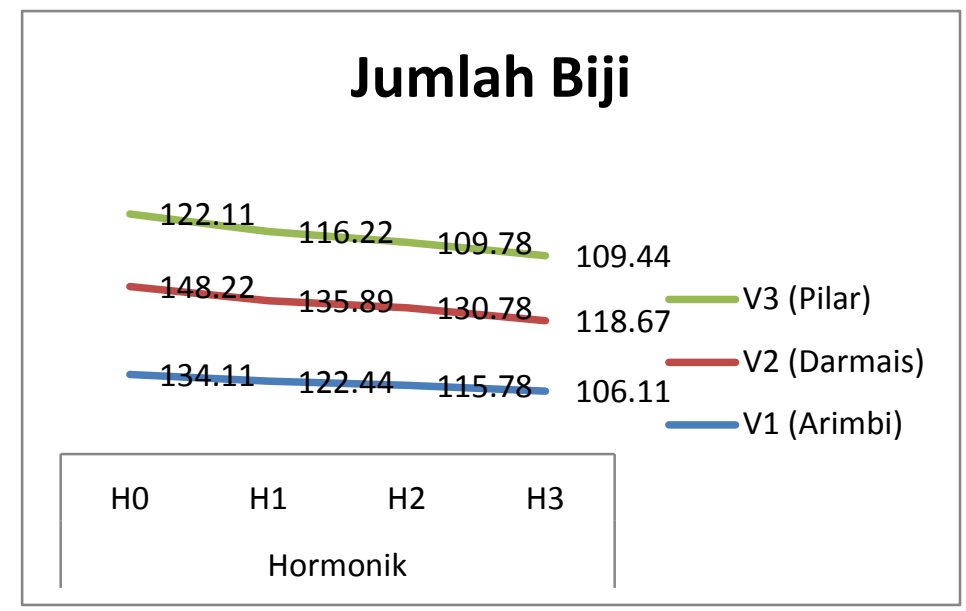

Grafik 4. Jumlah Biji Cabai Besar

Dari hasil penelitian yang telah dilakukan, menunjukkan bahwa perlakuan zat pengatur tumbuh hormonik berpengaruh sangat nyata pada semua parameter pengamatan, yaitu berat buah pertanaman, jumlah buah pertanaman, panjang buah per sampel dan jumlah biji buah persampel (Grafik 1-4). hal ini menunjukkan bahwa kedua faktor saling berhubungan, adanya perbedaan yang nyata ini karena adanya keseimbangan antara perlakuan hormonik terhadap varietas, semua parameter tersebut dilakukan uji lanjut dengan menggunakan uji BNT 5\% maka hasil yang diperoleh tidak berbeda nyata pada parameter berat buah pertanaman saat panen pertama, dan jumlah buah pertanaman panen pertama, namun berbeda nyata terhadap parameter panjang buah persampel dan jumlah biji buah persampel, pemberian ZPT pada tanaman mampu meningkatkan berat buah dan jumlah buah pertanaman hingga 27\% (Gelmesaet al., 2010; Rolistyo et al., 2013).

Pada Grafik 1. Berat buah tertinggi berada pada perlakuan tanpa hormonik 0 cc sedangkan yang terendah berada pada perlakuan hormonik $1 \mathrm{cc}$, dan varietas yang memiliki berat buah tertinggi terdapat pada varietas Darmais apabila dibandingkan dengan varietas Arimbi dan varietas Pilar. Jumlah buah tertinggi berada pada perlakuan tanpa hormonik 0 cc dan yang terendah berada pada perlakuan hormonik $1 \mathrm{cc}$, untuk varietas yang mempunyai jumlah buah terbanyak terdapat pada varietas Arimbi dibandingkan dengan varietas Darmais dan Pilar, adanya perbedaan jumlah produksi pada setiap varietas yang berbeda dengan perlakuan zat pengatur tumbuh hormonik yang sama, ini disebabkan karena adanya pengaruh yang dominan terhadap sifat-sifat genetik dari varietas itu sendiri, selain itu pengaruh lingkungan seperti suhu, kelembaban tingkat keseragaman pertumbuhan tanaman pada setiap perlakuan berbedabeda.

Pada Grafik 2. Terlihat menurunkan pertumbuhan dan produksi tanaman, baik secara kuantitatif maupun kualitatif, hal ini karena adanya pengaruh sifat genetik pada setiap varietas tersebut, dan terserang penyakit virus Gemini dan 
penyakit bercak daun. Penyakit virus Gemini atau virus kuning karena salah satu gejala serangan virus ini adalah daun tanaman mengeriting dan muncul bercakbercak coklat dengan lingkaran kuning atau terlihat seperti belang-belang kuning. Dampak dari serangan virus ini adalah pertumbuhan tanaman terhambat, dan tanaman tidak bisa menghasilkan buah (Syamsidi et al., 1997; Makhliza et al., 2014).

Virus menular dari satu tanaman ketanaman lainnya melalui perantaraan vektor atau inang penular, tanpa bantuan virus ini tidak memiliki kemampuan untuk berpindah dari satu tanaman ketanaman lain, sekalipun jarak antara satu tanaman dengan tanaman lain sangat berdekatan. Adapun vektor atau inang penyebaran virus pada tanaman cabai antara lain kutu thrips, tungau, kutu persik, kutu kebul dan beberapa jenis nematoda. Selain itu, penularan virus bisa juga melalui alat pertanian yang digunakan, tangan manusia, atau bahkan terbawa melalui benih yang sudah terinfeksi virus. Gejala serangan virus tidak langsung tampak seketika virus baru menginfeksi tanaman (Suriana, 2013).

Adapun gejala yang tampak pada tanaman cabai yang terserang penyakit bercak daun berwarna putih pada tepi daun dan bercak berwarna kecoklatan sehingga daun perlahan-perlahan berubah menjadi kuning, penyakit bercak daun disebabkan oleh cendawan cercospora capsici, daun cabai akan dipenuhi bercakbercak putih yang awalnya kecil kemudian akan membesar, pada bagian pinggir daun terdapat bercak berwarna lebih tua dari warna bercak tengahnya, biasanya berwarna coklat. Serangan yang berat menyebabkan daun menguning dan gugur, atau langsung gugur tanpa didahului oleh menguningnya daun tanaman cabai yang terinfeksi penyakit ini menunjukkan gejala adanya bercak-bercak bulat kecil kebasahan pada daun. Lamakelamaan bercak tersebut meluas, bagian tengah (pusat) berwarna pucat keputihan dan bagian tepi berwarna lebih gelap. Kemudian daun akan segera menguning dan gugur, atau langsung gugur tanpa menguning terlebih dahulu. Cendawan ini juga menyerang batang tanaman, tangkai daun, dan tangkai buah (Syukur et al., 2012; Cahyono, 2014).

Tanaman yang terserang penyakit ini menyebabkan daun cabai menjadi rusak, sehingga mengganggu proses fotosintesis. Tanaman yang terserang penyakit ini menurunkan produktivitas tanaman cabai besar dan menunjukkan hasil buah yang kurang optimal dan tanaman menjadi kerdil, sehingga kualitas buah yang dihasilkan menurun, selain itu juga jumlah daun berkurang, banyaknya daun yang gugur, sehingga dapat menghambat pertumbuhan tanaman dan pembentukan buah sekitar 17\% (Hamid dan Haryanto, 2011). Selain penyakit yang menyerang pada daun dapat juga terjadi kerusakan pada batang, bunga, dan tangkai buah, yang menyebabkan kerontokan. Akibatnya pertumbuhan dan produksi tanaman cabai menjadi terhambat, bahkan tanaman gagal panen dan mati.

Panjang buah tertinggi berada pada perlakuan hormonik $3 \mathrm{cc}$, yang terendah berada pada perlakuan tanpa hormonik 0 cc, dan varietas Arimbi memiliki panjang 
buah terpanjang dibandingkan dengan varietas Darmais dan Pilar. Jumlah biji buah tertinggi berada pada perlakuan tanpa hormonik 0 cc dan terendah berada pada perlakuan hormonik $3 \mathrm{cc}$, dimana varietas Pilar memiliki jumlah biji yang lebih sedikit dibandingkan dengan varietas Arimbi dan Darmais.Pada perlakuan $3 \mathrm{cc}$ dapat mengurangi jumlah biji pada buah cabai sekitar $\pm 30 \%$ dibandingkan dengan kontrol, pemberian hormonik dapat mempengaruhi pembentukan buah dan biji. Pemberian ZPT berpengaruh terhadap pembentukan buah partenokarpi yaitu dari segi panjang buah dan jumlah biji buah (Annisah, 2009; Barahima, 1998). Pemberian ZPT dari luar (secara eksogen) membuat biji tidak lagi berkembang karena pertumbuhan dan pembesaran buah dikosongkan dari luar. Ada buah yang terjadinya harus ada biji, ada pula buah yang dapat tumbuh dan berkembang tanpa biji, bahkan ada buah yang terbentuk dan tumbuh tanpa pembuahan. Pertumbuhan upnormal dapat terjadi pada proses pembentukan biji, ada biji yang berkembang tanpa pembuahan bahkan tanpa penyerbukan (Suwanto, 2009).

Biji tidak hanya mengandung hormon giberelin tetapi mengandung auksin, bagi tumbuhan biji merupakan tempat cadangan auksin, dengan pemberian auksin dan giberelin dapat menggantikan peran biji, sehingga tumbuhanpun tidak perlu menyimpan kedua hormon tumbuh itu dalam biji sehingga biji tidak terbentuk. Auksin merupakan hormon pertumbuhan bagi tanaman dan auksin bekerja dengan mempengaruhi metabolisme kearah sinar matahari, giberelin mempengaruhi meristem dan respon tanaman terhadap suhu, cahaya, serta pembentukan bunga, buah, dan biji, Sitokinin mengatur pertumbuhan, daun, buang dan buah.

Auksin dan Giberelin yaitu untuk menghilangkan biji pada beberapa buah seperti anggur. Auksin dibutuhkan selama perkembangan buah (Pardal, 2001). Giberelin mengakibatkan tidak terbentuknya biji karena gangguan pertumbuhan tabung sari sebelum pembuahan, tingkat keberhasilan penghilangan biji ini mencapai hampir 100\% (Suwanto, 2009).

\section{KESIMPULAN}

Hasil penelitian dapat disimpulkan bahwa

1) Pemberian hormonik pada tiga varietas tanaman cabai besar dapat mempengaruhi berat buah, jumlah buah, panjang buah dan jumlah biji.

2) Semakin tinggi dosis hormonik maka jumlah biji buah cabai semakin berkurang.

\section{UCAPAN TERIMAKAIH}

Terimakasih kepada mahasiswa Fazwati, Nely, dan Nori yang telah membantu di lapangan.

\section{DAFTAR PUSTAKA}

Barahima. 1998. Induksi Pembentukan Buah Tomat Tanpa Biji dengan menggunakan Giberelin. Jurnal Irian Jaya Agro IV (1). Hal 8-12.

Cahyono, B. 2014. Rahasia Budidaya Cabai Merah Besar \& Keriting Secara Organik dan Anorganik. Pustaka Mina. Jakarta.139 Hal. 
Gelmesa. Dandane. Bekele dan Lemma. 2010. Effects of Gibberellic acid and 2,4 dichlorophenoxyacetic acid spray on fruit yield and quality of Tomato (Lycopersicum esculentum Mill.). Journal of Plant Breeding and Crop Science Vol. 2 (10) pp 316-324.

Hamid, A. dan Haryanto, M. 2011. Bertanam Cabai Hibrida untuk Industri. Agro Media Pustaka. Jakarta.194 Hal.

Makhliza, Z. Sitepu, F. E. T,. dan Hayati. 2014. Respon Pertumbuhan dan Produksi Tanaman Semangka (citrullus vulgaris Schard.)terhadap Pemberian Giberelin dan Pupuk TSP. Jurnal Online Agroekoteknologi. ISSN No. 23376597. Vol.2, No.4 : 1654-1660, September 2014.

Pardal, S. J. 2001. Pembentukan Buah Partenokarpi melalui Rekayasa Genetika. Balai Penelitian Bioteknologi Tanaman Pangan, Bogor. Jurnal Buletin AgroBio. Vol. 4. No. 2. Hal. $45-49$.

Rolistyo, A. Sunaryo. dan Wardiyati, T. 2014. Pengaruh Pemberian Giberelin terhadap Produktivitas Dua Varietas Tanaman Tomat (Lycopersicum esculentum Mill). Jurnal Produksi Tanaman. 2014. Vol. 2. No. 6.Hal. 457-463.

Suriana, N. 2013. Budidaya Cabai Di Lahan Sempit. Infra Pustaka. Riau.140 Hal.

Suwanto A, 2009. Berbahayakah Semangka dan Anggur Tanpa Biji. http://inspiration-bioteknologi. kompas.com/2009/06/semangkadan-anggurtanpa-biji-doktor.

Syamsidi, S.R., T. Hasdiatono., dan S.S Putra. 1997. Ketahanan cabai merah terhadap Cucumber Mosaic Virus (CMV) pada umur tanaman pada saat inokulasi. Prosiding Kongres Nasional XIV dan Seminar IImiah. Perhimpunan Fitopalogi Indonesia.
Syukur, M. Yunianti, R.dan Dermawan, R. 2012. Sukses Panen Cabai Tiap Hari. Penebar Swadaya. Jakarta. 148 Hal. 